\title{
Coconut oil reduces protozoa count and methane release during fermentation in a Rusitec system
}

\author{
A. Cieślak1, M. Szumacher-Strabel, E. Szymankiewicz, M. Piękniewski, \\ P. Oleszak, L. Siwiński and A. Potkański
}

The August Cieszkowski Agricultural University of Poznań, Department of Animal Nutrition and Feed Management

Wotyńska 33, 60-637 Poznań, Poland

\begin{abstract}
The influence of coconut oil on microbial activity was investigated in vitro using a rumen simulation technique (Rusitec). Diets containing either 40 (L-diet) or 60\% (H-diet) of concentrate and 60 or $40 \%$ hay, respectively, were supplemented with coconut oil at the rate of $5 \%$ DM (experimental cultures) or given alone (control cultures). Coconut oil significantly reduced ciliate numbers and methane concentration independently of the $\operatorname{diet}(\mathrm{P}<0.05)$. Bacteria numbers increased significantly (L-diet) or remained unaffected (H-diet) And, conversely, the ammonia concentration remained unchanged (L-diet) or decreased (H-diet). Coconut oil had no effect on the molar proportions of acetate, propionate, or butyrate.
\end{abstract}

KEY WORDS: coconut oil, medium-chain fatty acids, methane, Rusitec

\section{INTRODUCTION}

The majority of gases produced by ruminants originate from rumen fermentation (Demeyer and Fievez, 2000). Due to massive methane emission from agriculture, several inhibitors have been tested in both in vivo and in vitro systems. Supplementing ruminants' diets with oils rich in either unsaturated or saturated fatty acids is one of the tested models. It has been shown that such fats can negatively affect microbial activity in the rumen and reduce methane release. The effect of fat depends, however, on the forage-to-concentrate ratio in the diet (Machmüller, 2006).

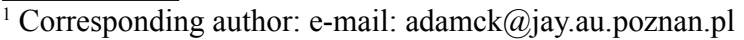


High-yielding ruminants are usually fed a starch-rich diet but it is still difficult to cover the energy requirements of the animal. One of the alternatives may be supplementing fat to the ration. Since an elevated level of fats may negatively affect fibre degradation as well as rumen fermentation, protected forms of fat are recommended. Coconut oil is one of the most frequently used protected fats in ruminant nutrition. Therefore, the aim of the present study was to evaluate the effect of coconut oil on the activity of rumen microorganisms grown in vitro using a rumen simulation technique (Rusitec) and diets characterized by different hay/ concentrate ratio.

\section{MATERIAL AND METHODS}

Two diets containing different forage-to-concentrate ratios were used. The lowconcentrate diet (L-diet) consisted of $60 \%$ meadow hay and $40 \%$ wheat meal, whereas the high concentrate diet (H-diet) was composed of $40 \%$ meadow hay and $60 \%$ wheat meal. Coconut oil rich in lauric (47.47\% FAME) and myristic (19.15\% FAME) acids was supplemented to each of the experimental diets at the rate of $5 \%$ of dietary dry matter. The study was performed using the Rusitec system (Czerkawski and Breckenridge, 1977). Each of the four fermenters ( $1 \mathrm{~L}$ in volume) was filled with $100 \mathrm{ml}$ pre-warmed buffer solution (artificial saliva; Czerkawski and Breckenridge, 1977) and $900 \mathrm{ml}$ strained rumen fluid collected from a rumen fistulated cow. The nylon bags $(70 \times 130 \mathrm{~mm})$ had a pore size of $100 \mu \mathrm{m}$ as recommended by Carro et al. (1995). The average daily feed supply was $11 \mathrm{~g}$ of dry matter (DM). The turnover rate of the liquid was $500 \mathrm{ml} \mathrm{d}^{-1}$. The experimental periods lasted 10 days and consisted of a 4-day adaptation period of the rumen microbes to the system and diet and 6 days of sample collection. During the last 5 days of the experiment, the sampling was performed every day. The following were determined: $\mathrm{pH}$, ammonia (by the Nessler reagent), volatile fatty acids and methane (by gas chromatography). The protozoa and bacteria were counted under a light microscope using Bürker and Thoma counting chambers, respectively. Statistical evaluation was carried out by analysis of variance (SAS, 2006). Multiple comparisons among means were carried out by Duncan's test.

\section{RESULTS}

Coconut oil significantly $(\mathrm{P}<0.05)$ reduced protozoa number, whereas bacteria were either elevated (L-diet) or remained unchanged (H-diet) (Table 1). The methane concentration decreased by $40-42 \%$ independently of the forage/ concentrate ratio, while ammonia remained unchanged (L-diet) or decreased by 
about 36\% (H-diet). Significant interactions were found between diet composition (forage-to-concentrate ratio) and VFA level. Coconut oil had no effect on the molar proportion of particular acids.

Table 1. Microbial population density and fermentation product concentration in the fermenters given feed alone (control) or supplemented with coconut oil (experimental). Mean values $(n=4)$

\begin{tabular}{lrcrrr}
\hline \multirow{2}{*}{ Item } & \multicolumn{2}{c}{ L-diet } & & \multicolumn{2}{c}{ H-diet } \\
\cline { 2 - 3 } \cline { 5 - 6 } \cline { 5 - 6 } & control & experimental & & control & experimental \\
\hline Protozoa, $10^{4} \mathrm{ml}^{-1}$ & $3.34^{\mathrm{a}}$ & $0.95^{\mathrm{b}}$ & & $3.05^{\mathrm{a}}$ & $0.95^{\mathrm{b}}$ \\
Bacteria, $10^{7} \mathrm{ml}^{-1}$ & $34.80^{\mathrm{c}}$ & $41.20^{\mathrm{b}}$ & & $46.70^{\mathrm{ab}}$ & $51.80^{\mathrm{a}}$ \\
Methane, mmol/1 & $4.36^{\mathrm{a}}$ & $2.60^{\mathrm{b}}$ & & $3.70^{\mathrm{a}}$ & $2.16^{\mathrm{b}}$ \\
$\mathrm{pH}$ & $6.98^{\mathrm{a}}$ & $6.91^{\mathrm{a}}$ & & $6.96^{\mathrm{a}}$ & $6.96^{\mathrm{a}}$ \\
Ammonia, mmol/1 & $16.21^{\mathrm{a}}$ & $15.75^{\mathrm{a}}$ & & $10.85^{\mathrm{b}}$ & $6.96^{\mathrm{c}}$ \\
Total VFA, mmol/1 & $46.93^{\mathrm{ab}}$ & $41.94^{\mathrm{b}}$ & & $48.53^{\mathrm{a}}$ & $44.33^{\mathrm{ab}}$ \\
Acetate, A \% & $47.94^{\mathrm{b}}$ & $49.13^{\mathrm{a}}$ & & $51.90^{\mathrm{a}}$ & $50.57^{\mathrm{a}}$ \\
Propionate, P \% & $20.91^{\mathrm{a}}$ & $18.78^{\mathrm{ab}}$ & & $16,36^{\mathrm{b}}$ & $18.04^{\mathrm{ab}}$ \\
Butyrate, \% & $14.74^{\mathrm{a}}$ & $16.42^{\mathrm{a}}$ & & $16.82^{\mathrm{a}}$ & $16.16^{\mathrm{a}}$ \\
Others, \% & $16.41^{\mathrm{a}}$ & $15.67^{\mathrm{a}}$ & & $14.92^{\mathrm{a}}$ & $15.32^{\mathrm{a}}$ \\
A/P & $2.29^{\mathrm{a}}$ & $2.61^{\mathrm{a}}$ & & $3.17^{\mathrm{a}}$ & $2.80^{\mathrm{a}}$ \\
\hline
\end{tabular}

means with the same letter are not significantly different; ${ }^{\mathrm{a}, \mathrm{b}}$ - $\mathrm{P} \leq 0.05$

\section{DISCUSSION}

Certain fats and oils are potential natural methane-reducing feed compounds, effective even at common dietary proportions (Machmüller et al., 1998). Such an effect was demonstrated for unsaturated and saturated fatty acids (Zinn, 1988; Van Nevel and Demeyer, 1996). Coconut oil, a source of saturated medium-chain fatty acids, has previously been used as a methane inhibitor (Machmüller et al., 1998). Recently, Machmüller (2006) concluded that a 50\% reduction of in vitro methane production may be possible even when less than $3 \%$ of medium-chain fatty acids $(\mathrm{C} 12: 0, \mathrm{C} 14: 0)$ is supplemented to diets. In this study, methane release was reduced by about $40 \%$ in the case of both diets, regardless of the forage-to-concentrate ratio. Decreased methane production is usually accompanied by a reduction in the number of protozoa resulting from the increased dietary fat concentration. Similar results were presented by Machmüller et al. (1998), who observed depressed methane production when coconut oil was supplemented to the diet. Moreover, the continuous elimination of protozoa from the cultivated microbial population was observed between the fourth and the ninth day of fat administration. Methane inhibition was accompanied by a lower ammonia concentration in H-diets and a higher bacteria count in L-diets. In the present study, the highest bacteria count in the L-diet supplemented with coconut oil resulted from the reduced number of protozoa, which was observed in earlier studies (Jouany, 1994). It may be 
hypothesized that coconut oil exerts a stimulatory effect on rumen bacteria, but only in the case of the L-diet. According to Henderson (1973), the inhibitory effect on fibre-degrading microbes is more evident for long-chain fatty acids than for medium-chain ones. On the other hand, a high-concentrate diet supplemented with fat may exert a more negative effect on the microbial population than a forage-rich one (Machmüller, 2006).

\section{CONCLUSIONS}

Coconut oil reduced ciliate number and methane concentration independently of diet composition, which could reflect the susceptibility of protozoa and/or methanogens to the elevated level of fat in the ration. The reduction in methane concentration can be also considered as a result of the decrease in the numbers of methanogens, since a significant part of these microorganisms remains closely associated with the ciliate cells as intra- or extracellular symbionts.

\section{REFERENCES}

Carro M.D., Lebzien P., Rohr K., 1995. Effect of pore size of nylon bags and dilution rate on fermentation parameters in a semi-continuous artificial rumen. Small Ruminant Res. 15, 113119

Czerkawski J.W., Breckenridge G., 1977. Design and development of a long-term rumen simulation technique (Rusitec). Brit. J. Nutr. 38, 371-384

Demeyer D., Fievez V., 2000. Ruminants et environnement: la méthanogenèse. Ann. Zootech. 49, 95-112

Henderson C., 1973. The effect of fatty acids on pure cultures of rumen bacteria. J. Agr. Sci. 81, 107-112

Jouany J.P., 1994. Manipulation of microbial activity in the rumen. Arch. Anim. Nutr. 46, 133-153

Machmüller A., 2006. Medium-chain fatty acids and their potential to reduce methanogenesis in domestic ruminants. Agr. Ecosyst. Environ. 112, 107-114

Machmüller A., Ossowski D.A., Wanner M., Kreuzer M., 1998. Potential of various fatty feeds to reduce methane release from rumen fermentation in vitro (Rusitec). Anim. Feed Sci. Tech. 71, 117-130

Van Nevel C.J., Demeyer D.I., 1996. Control of rumen methanogenesis. Environ. Monit. Assess. 42, 73-97

Zinn R.A., 1988. Comparative feeding value of supplemental fat in finishing diets for feedlot steers supplemented with and without monensin. J. Anim. Sci. 66, 213-227 